\title{
Representation of the female members of YPJ in british media
}

\author{
Ana Luiza Moreira Mineiro Drummond \\ Maria Luiza Siqueira Batista \\ Cristiano Garcia Mendes
}

\begin{abstract}
This paper aims to identify how the YPJ fighters have been framed in British media and to what extent these portrayals reflect misconceptions not only related to their gender, but also to a westernized judgment of their choices. In order to accomplish this, a qualitative analysis was employed based on a compilation of articles released by the BBC and The Guardian between 2014 and 2018.
\end{abstract}

Keywords: Kurdish Female Fighters. YPJ. Media. Orientalism. Gender.

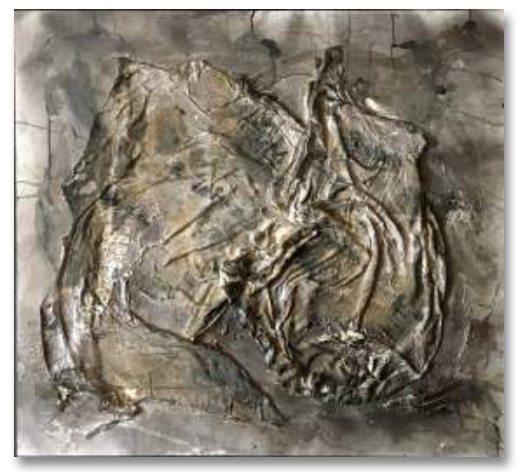

\section{Representação das combatentes do YPJ na mídia britânica}

Ana Luiza Moreira Mineiro Drummond

Mestranda do Programa de Pós-Graduação em Relações Internacionais e graduada em Relações Internacionais pela Pontifícia Universidade Católica de Minas Gerais (PUC - Minas).

E-mail: analuizamdrummond@gmail.com

\section{$\overline{\text { Maria Luiza Siqueira Batista }}$}

Mestranda do Programa de Pós-Graduação em Relações Internacionais e graduada em Relações Internacionais pela Pontifícia Universidade Católica de Minas Gerais (PUC - Minas).

E-mail: mlsbatista.ri@gmail.com

\section{$\overline{\text { Cristiano Garcia Mendes }}$}

Docente na graduação e no Programa de Pós-graduação em Relações Internacionais da Pontificia Universidade Católica de Minas Gerais. E-mail: cristianomendes@gmail.com
Resumo: Este artigo objetiva identificar como as combatentes do YPJ foram representadas na mídia britânica e em que medida esses retratos refletem conceitos errôneos não apenas relacionados ao seu gênero, mas também a um julgamento ocidentalizado de suas escolhas. Para isso, foi empregada uma análise de conteúdo qualitativa, com base em uma compilação de artigos publicados pela $\mathrm{BBC}$ e pelo The Guardian entre 2014 e 2018.

\section{Palavras-chave:}

Mulheres Combatentes Curdas. YPJ. Mídia. Orientalismo. Gênero.

RECEBIDO: 23/06/2020

Aprovado: $12 / 10 / 2020$ 


\section{Introduction}

Traditionally, warfare is considered an almost-exclusively male activity. Most of what is known about armed conflicts is told by the words and voice of men. The roles taken by women have historically been more passive and female combatants are merely seen as victims and targets of physical or sexual violence, rather than fighters who have agency (BASER; TOIVANEN, 2016). In a different manner, women in Kurdistan are a substantial part of the insurgency and make up one of the most important armed groups of the country, recognized for confronting conventional gender expectations and redefining the conflict dynamic in the region, the Yekîneyên Parastina Jin (YPJ) (FERREIRA; SANTIAGO, 2018).

This Kurdish female-led security force became widely known during brutal attacks of the Islamic State (IS) against the city of Kobane, in northern Syria, on September 2014. On that occasion, the YPJ female fighters made the headlines of mainstream international newspapers for their remarkable achievements on the aforementioned battle, and were portrayed as carriers of Western secular values against a radical and violent religious extremist group. As the media continued their fascination with them, a narrative characterized by heroization and gendered geopolitics was produced and extensively disseminated (JONGERDEN; SIMSEK, 2018).

Accordingly, the representation of the conflict between these oppositional forces in Western media, also seen as the civilized West against the barbaric "other", contains an interrelated dimension of gender and orientalism (BASER; TOIVANEN, 2016). While female fighters of the IS are depicted as heartless brides or brainwashed victims of men, the Kurdish combatants are glorified for their beauty, bravery and freedom. In this respect, these differences suggest how gender stereotypes are instrumentally used by media channels for a biased westernized discourse (ESKANDARI, 2018).

On this matter, this paper is an enquiry into the understanding as to how the representation of YPJ fighters by the media tends to reflect geopolitics influence on gender misconceptions. To that end, the aim of this study is to investigate how the two most popular British news channels, the British Broadcasting Corporation (BBC) 
and The Guardian, have portrayed the Kurdish fighters in the war against the IS from 2014 to 2018, and what are the reasons behind it. Additionally, these representations will be explored in juxtaposition to the repercussion of those who join terrorist groups, such as the IS, to commit similar acts.

For that purpose, the theoretical framework used in this article has feminist IR theories as our starting point, referring to authors such as J. Ann Tickner, Jacqui True and Laura Sjoberg. Furthermore, the discussion relies upon the main concepts of orientalism, having Edward Said's approach as its main foundation. Through these lenses, this examination critically delves into questions that may open up ways to map how Western media, embedded in misconceptions and contradictions, builds its speech to favour dominant interests and consequently reinforces gender discriminations.

In order to encompass such debates, the research conducts a methodology approach of content analysis (CA) which provides a systematic means for quantifying textual and thematic features across a large number of texts (HANSEN, 1998). This technique allows the inference of knowledge related to the conditions of production and reception of the messages, easing the interpretation of their meanings in a non-obvious and non-literal way (BARDIN, 2011). Hereof, CA will be applied to the articles published by the mainstream online newspapers in the United Kingdom regarding YPJ combatants.

The sample selection is limited to articles released between January 2014 and December 2018, due to the spreading of YPJ narratives in the media after the Siege of Kobane, in 2014, and the return of fighters to the UK, four years later, and to the first page of search results, from each of the aforementioned channels, of terms directly related to the research question, which are: "YPJ", "Kurdish", "women", "woman", "female". It is worth mentioning that since Google search engine collects user data in order to tailor better results and provide a better searching experience, results may vary for subjective reasons.

Subsequently, the selected articles will be exported to the MAXQDA software, a program designed for the analysis of qualitative data which was chosen due to its powerful visualization tools, 
and will be examined through classification schemes that involves the identification of recurrent patterns and of words combinations in their respective contexts, and the generation of lexical lists. At the end of process, it will be possible to build up a cohesive representation of the data and to create figures that shows the discourse strands of BBC and The Guardian about YPJ fighters.

This paper is organized into five sections. Firstly, a short literature review of feminist IR theories is outlined, including a brief overview of field emergence and development, major definitions and core concepts, and its broad contributions to the discipline. Following this, the feminist work is situated in the larger field of Security Studies, placing a strong focus on the roles that women play in conflict and in issues regarding this gender perspective, and a discussion of the way in which gender and orientalism may interrelate is presented. The third section offers a contextual introduction to the case study, providing a historical background for the presence of female combatants in Kurdish forces and their contributions to the ongoing conflict in the region. Next, the fourth section proceeds to explore the discourse of BBC and The Guardian on YPJ fighters and to demonstrate how these representations reflect stereotypes, misconceptions and geopolitical interests. Finally, the last section concludes on the main findings of the research and presents some key next steps and other opportunities for this agenda.

\section{Feminism and international relations}

Simply put, feminist theories challenge the male way in which the International Relations have been conceptualised, leaving women's experiences at the margins of the discipline. In this sense, feminists analyze relations of power involving men and women and how such interaction has been historically and socially implemented over time, in order to open space for gender in major theoretical debates. Prior to presenting a brief context of IR feminist narratives and its main ideas and premises, it is important to define two key terms for this approach (NARAIN, 2014; RUIZ, 2004). 
First, gender is not the equivalent of the biological characteristics described by the term "sex". Instead, it refers to the complex social construction of men's and women's identities and to the culturally specific notions of men's and women's behaviour, especially in relation to each other (THORBURN, 2000). These symbolisms describe masculine/feminine dichotomies that are fundamental to power dynamics between genders, where terms associated with masculinity tend to receive a higher value. Therefore, gendered social hierarchy reflects a structural feature of social and political life that profoundly shapes the world (WILCOX, 2009).

The second crucial term to feminist theory is patriarchy, defined as a system in which women are subordinate to men in power and status, according to the belief that women's biological inferiority is related to her reasoning capabilities. In this regard, feminists aim to reveal the gendered dimensions of theories, structures and actions, bringing to light women's issues and struggles (RUIZ, 2004). In International Relations arena, the world in seen through gendered lenses to focus on this particular kind of power relations and to trace out ways in which they are central to understanding international processes (SJOBERG, 2009).

This approach was fueled by the end of the Cold War and the consequent decline in the preponderance of military-security issues, when IR field faced serious challenges to its core theoretical structure. At that time, new disciplinary areas emerged and calls for the rethinking of the field's foundations increased, opening up space for revolutionary changes in the study of world politics. In this wave, feminist theories came to IR and began to develop critiques of the discipline's mainstream concepts, claiming that they did not recognize its gendered foundations nor did they speak to broad gender issues (TICKNER, 2000).

Raising these questions, feminist scholars argue that IR is in itself male-centered, marginalizing female perspectives, knowledge and experiences that should be brought to bear on the analysis of international relations (TICKNER, 2000). Accordingly, power relations inherent in international structure are legitimized in the relation between men and women, which has resulted in a study entrenched in gender bias (THORBURN, 2000). Hence, feminists 
belief that gender subordination is constitutive of the global political world, and commit to examine this relationship between knowledge and power and to contribute to the lessening of women's subordination (SJOBERG, 2009).

As such, these understandings point to the gendered nature of states that promote and support policy practices in the interests of men, and suggest that international politics is dominated by the construction and reproduction of masculine identities (TICKNER, 2000). Moreover, as they are sensitive to the differences in female's position, feminists take individuals into account and seek to identify women's agency in IR, even of those in marginalized conditions. Consequently, the analysis of international politics frequently involves intimate relationships, personal identities and private lives, and not only places for "high politics" (TRUE, 1996, p. 247).

On the whole, feminists have sought to demonstrate that gender relations are at the heart of international processes. However, despite this epistemological and conceptual unity, they can approach global politics from a number of different perspectives, such as realist, liberal, constructivist, critical, poststructural, postcolonial, and ecological (SJOBERG, 2009). While from the realist angle feminist works are interested in the role of gender in strategy and power politics between states, liberal works acknowledge the inferior and subordinate position of women in international affairs and advocate for their inclusion in the existing structures of politics (SJOBERG, 2009).

Critical feminism, in its turn, delve into the ideational and material expressions of gendered identity and gendered power in world politics, and feminist constructivism explores how ideas and perceptions on gender shape and are shaped by a macrostructure. On the other hand, feminist poststructuralism calls attention to the ways in which gendered linguistic manifestations constitute international relations by empowering the masculine and diminishing the feminine. Finally, postcolonial feminists inquire into how gender hierarchy is reflected in colonial relations of domination and subordination, and ecological feminism focuses on the treatment of women and other minorities and its relation to the nonhuman environment (SJOBERG, 2009). 
Considering the research objective, it is opportune to further describe the feminist poststructuralist perspective so as to better explain the relationships between the key categories of the analysis. By providing ways to examine socially available discourses and ways in which people take them up, this approach opens up the possibility of interpreting the media's representation of YPJ female fighters and of identifying social, political, historic and economic influences that construct and define its categories (BARRET, 2005). Respectively, it is built under the understanding that language, and therefore discourse, constitutes meanings specific to particular groups, cultures and historical periods (GAVEY, 1989).

Thus, it is a structuring principle of society through which material power is exercised and power relations are established and perpetuated. In this regard, meanings are actively constituted through language and are neither innocent or neutral, but reflect the subject's position in the world. As different positions produce different levels of authority, discourses that support existing power relations tend to constitute the subjectivity of most people most of the time. Consequently, feminist discourses are normally limited in their power because they are marginalized and unavailable to many women (GAVEY, 1989).

Hence, in any society, dominant discourses reflect particular values and gender interests. These elements have to be understood in the context of widely held beliefs about female sexuality and women's proper place and lifestyle which cross many discursive fields, including the representation of them in the media. Thereby, a woman may be seen as a freedom fighter when she was a terrorist and vice versa, depending on the discursive position from which they are received and interpreted. In this respect, the meaning of the existing social structure and of the subject positions is a site of political struggle waged in language (WEEDON, 1989).

In sum, then, feminist poststructuralism uses language, subjectivity and social processes to understand existing power relations, to explain it on behalf of specific interests and to analyse the opportunities for resistance to it. Therefore, this theory can help in offering explanation alternatives of where does media discourse on women come from, why it is contradictory or 
incoherent and why and how it can change. It can also account for the material relations and practices that constitute individuals as subjects with particular desires, preferences and ideologies which are the effect of social institutions and which also structure society (WEEDON, 1989).

As this section have shown, feminist perspectives on IR take on paths that venture far from the conventional discipline (TICKNER, 2000). They emphasize the gender dichotomies that organize social activity, the gender hierarchy that serve to support male power and female subordination, the sexist stereotypes that reinforce women's marginalization and the traditional women's roles in society. As a result, they draw on local knowledge to construct their theories and they offer new ways of analyzing many practices on global politics, such as the representation of women fighters on Western media.

\subsection{Feminist Security Studies}

As previously discussed, the field of IR remained for a long time as an area mainly occupied by male scholars. Nonetheless, the advancements made by feminist theories highlighted the importance to include gender as an important topic in order to understand the dynamics of international politics. Even so, one could argue, how issues of war, conflict and violence, still remain considerably gendered. Author Laura Sjoberg (2009) points out how such perception was responsible for creating a certain gap between Security Studies and Feminist theories, despite the growing influence of the latter in IR. It was only by the 1970s that Security Studies, under the influence of Johan Galtung's work on structural violence, started pointing out discussions about the impact of violence on women.

Such contributions were responsible for the emergence of so-called Critical Security Studies which, among other aspects, expanded the concept of violence and peace to incorporate "a host of issues related to economic differences between the global North and South" (BUZAN et al., 2009, p. 123). According to Galtung (1969), violence can be experienced at both personal and 
structural level, whilst peace is also divided between negative and positive. In this sense, the idea of structural violence included the debate on social injustice which "referred to manifest injustices with physical material consequences, for instance hunger-related deaths in the Third World, but also to phenomena with a less immediate bodily impact such as illiteracy" (BUZAN et al., 2009, p. 123). Consequently, the concept positive peace expanded the notion of the "absence of violence" (GALTUNG, 1969, p. 167) to include the promotion of social justice and, therefore, the absence of structural violence as well.

The aforementioned was essential to address the impact of violence on individual agents, however, it is argued that much focus still remained state-centric due to the Marxist influence on the field which lead to the assumption that "class relations were more fundamental, hence solving the problems of capitalist societies would also bring gender equality" (BUZAN et al., 2009, p. 138). Thus, although the concept of structural violence opened space to include women as directly affected by a society mainly designed for men, they were still not part of the discussions as agents, but rather as solely victims whose problems were still attempted to be solved by their male counterparts (SYLVESTER, 2010).

For instance, it was only in 2000 that the United Nations Security Council (UNSC) implemented Resolution 135 which mainstreamed gender in its operations by obligating member-states "to include women in peace negotiations and post-conflict reconstruction" (SJOBERG, 2009, p. 185). In this sense, these influences contributed to the emergence of what became known as Feminist Security Studies (FSS) which, given the multiplicity of Feminist theories, are argued to also have many different approaches to Security Studies. Having said that, as highlighted by Laura J. Shepherd (2015), FSS can be divided it into two main perspectives, as addressed below.

Some FSS scholars suggest that gender can be seen as a variable, which is a "stable descriptor of identity" (SHEPHERD, 2015, p. 12). In this sense, according to this perspective, gender can inform certain behavioural traits that are intrinsic to the nature of men and women and can directly impact on how security politics are formulated. As one notices, this approach closely dialogues with 
Feminist theories discussed in the previous section that imply a strong tendency of women to contribute with international security given their more pacifist nature and tendencies towards cooperative relations. However, the gender misconceptions in this perspective becomes clear when it generalizes, as well as idealizes, how female behaviour should be, and it does not acknowledge the particularities of each individual and the social context they are submitted to. Consequently, the implications can be deeply problematic as they deny women the capacity to exert agency irrespective of what it is assign to them, only because of their gender.

On the other hand, Shepherd (2015, p. 12) suggests a different approach to gender which treats it as "noun/verb/logic". In this sense, gender cannot inform about intrinsic traits of male and female behaviour, however, it is a category of analysis that is socially constructed and induces individuals to behave accordingly. Therefore, as previously discussed, according to this logic, gender is not equivalent to an objective biological category, instead, it is "a system of symbolic meaning that creates social hierarchies based on perceived associations with masculine and feminine characteristics" (SJOBERG, 2009, p. 187). The implications of this logic applied to Security Studies debates addresses the importance of including women in security talks not by implying their supposedly more pacifist and cooperative traits, but because they must be agents of political choices that affect them directly. Nonetheless, these scholars also acknowledge that, albeit there are no prescribed behavioural traits intrinsic to women and men, the environment in which they both live in may pose societal constraints that can be linked to their gender and impose to each one different outcomes and challenges.

Having said that, both approaches to FSS can potentially dialogue with different IR theories as discussed in the previous section. Nonetheless, due to the engagement of this work with the use of language to represent the involvement of women in violent activities, focus will be given to poststructuralist approaches. The contributions of poststructuralism to FSS derives from its central claim of how narratives, concepts and figurations are constructed and have direct impact on how a supposed reality is understood and, 
as a consequence, also inform how policies are generally adopted (BUZAN et al., 2009). Hence, such analyses are powerful tools to not only support the claims made by FSS against gender misconceptions in the construction of security, but they also confront how feminist discourse can also be bounded around constructed narratives that does not, necessarily, emancipate women from stereotypes of passive and submissive individuals. Moreover, poststructuralism contributes to FSS by addressing the necessary nuances to be acknowledged in feminist approaches that need to take identity into consideration in order to inform how women often experience and are affected by violence in different ways.

As this section discussed, the advancements made by FSS were extremely important to highlight the importance of recognising women victims of violence as well as agents to be included in decision-making and discussions around the topic. Even so, one argues how these discourses still remained centered in Westernised perceptions in which often excluded factors of different identities as crucial informants of how security narratives are constructed. In this sense, linking to how women are generally perceived, it is undeniable that women from different locations, ethnicities and social backgrounds have considerably different representations around them. Having said that, Orientalist approaches comes to light and will be further discussed as an important addition to confront perceptions of women in Security bounded by Western conceptions.

\subsection{Orientalist contributions to Feminist security Studies}

On 1978, Edward Said's Orientalism argued how dominant powers in the West, namely the British and French, had created narratives throughout history that framed Eastern civilizations as culturally and historically inferiors. The focus of Said's work is on the mystification of mainly Arab societies that are portrayed in the West through the attributions of a submissive, irrational and exotic woman (SAID, 1978). In this sense, it is argued how the West had constructed its imaginary around elements such as the veil and the harem as symbols of exotism and, and the same time, oppression (WEBER, 2001). In view of this, it is argued how First Wave 
feminists, despite claims of being accepted with equal rights as men, also relied on the belief that Orient attributions to women, irrespectively of their historical and political meanings, were a sign of oppression and underdevelopment. As author Charlotte Weber (2001, p. 127) points out, "with few exceptions, First Wave feminists of all stripes readily accepted a key element of the West's orientalist legacy-namely, the unquestioned belief in the superiority of "Western" ways".

One notices how such narratives are still present in Western representations of Arab civilizations, and are often used as means to justify interventions and impositions of so-called Western values. For instance, the United States government during the invasion of Afghanistan in 2001 is argued to have used the image of supposedly oppressed veiled women under Taliban rule as the backbone to sustain American actions in Afghan soil. It is noted, therefore, how Muslim women is generally portrayed by the West as oppressed and passive victims of the "barbaric nature of Muslim men" (MARTINI, 2018, p. 2). The idea of women using veils, burqa, or anything else used to cover them is seeing as a reflection of oppression and lack of liberty.

The aforementioned highlights how Orientalism is also present in certain approaches to so-called liberal feminism that create an image of the Other to represent women who do not share Western values. As a consequence, such figurations are based on the belief of the superiority of Western traits that creates dichotomies of acceptable and unacceptable forms of women to express agency and fight for their rights. The very idea of former President George Bush to export democracy to the world during the War on Terror as an alternative to save what he saw as barbaric societies, is a clear example of how Western narratives are imposed as superiorly more advanced than any other discourse. As author Roksana Bahramitash (2005) points out, the strategy used by Bush foreshadows what Said (1978) had argued to be the logic used by colonial powers in order to gain public support which focused on the alleged need to liberate women from the treatment they received in Islamic-based societies. 
As this section discussed, discourses based on Orientalism can construct images of how the West mostly frames Muslim women. In this sense, although feminist approaches can inform how women are generally perceived under the notion of patriarchy, it is only through the lenses of Orientalism that we can see how narratives construct images in Western perceptions of how women should behave and represent themselves. Having said that, the next sections will contextualize the case of the female members of YPJ to further discuss how they are represented in British media. In doing so, this paper will propose an analysis of the terms applied to these women by the media and how they carry a strong sense of Orientalist misconceptions to frame them in Western imaginary.

\section{Introduction to case study: YPJ}

As already stated, the YPJ is an all-female militia that has been battling against IS in Northern Syria for the last half-decade. However, women have been active-agents in Kurdish historymaking processes since the 1990s, when social movements regarding gender relations changed the region's structural dynamic. From then on, women developed a space of their own and started playing an important role in all spheres of society, mainly in politics. As key-actors, they established particular political parties, built non-governmental organisations and took part in significant nationalist issues (JONGERDEN; SIMSEK, 2018).

This revolution was supported by the Kurdistan Workers Party (PKK) leader, Abdullah Öcalan, who praised for a pro-feminist and anti-capitalist system. Öcalan became widely known as the strongest advocate for Kurdish sovereignty, and PKK is the political organisation founded by him with the initial aim of achieving an independent Kurdish state (ESKANDARI, 2018). At that time, PKK coined the term "jineology", built on the principle that no society can call itself free without the freedom of women within it, putting the liberation of women at the heart of the national struggles and vigorously encouraging female participation (GORMAN, 2017).

On the account that the Kurdish population has been partly concentrated in northern Syria, the PKK established connections 
with militant Palestinian organisations and, in the wake of the 1980 coup in Turkey, portions of it were dispersed to the referred country. In the earlies 2000, after the Syrian government banning Kurdish political parties, the Democratic Union Party (PYD) was founded by syrian kurds as a democratic confederalist political party striving for a multicultural society. In 2012, during the Syrian Civil war, the PYD established an armed military wing to protect the inhabitants of the region, the People's Protection Units (YPG) (ESKANDARI, 2018).

At this moment, thousands of women joined the militia, and their militarization became a strong focus point in the preservation of the Kurdish movement identity. Being a fundamental force to the region's defense, an autonomous women's unit were created in early 2013, the YPJ. In the following year, both organisations fought against the Islamic State of Iraq and Syria and were involved in the Siege of Kobane, when IS succeeded in capturing 350 Kurdish villages and towns and 300.000 Kurds were displaced. Soon after, due to the central role they played in the battle, female fighters became a symbol and the international enthusiasm for them vibrantly arouse (DEAN, 2019).

IS, a terrorist group that follows a fundamentalist jihadi doctrine, gained global prominence at that period for its videos of beheadings and other types of executions of both soldiers and civilians, and its destructive ground attacks in Western countries. As a result, the group was framed as the atavistic enemy of the "Christian West", as an aggressor towards civilization and as a threat to the values of the dominant society with its extremism, violence and intolerance (MANFRINATO, 2016). Thereupon, YPJ women were hailed in the media for their struggle against the radical Islam and were represented as carriers of secular values and as the face of the liberal forces beating villain jihadists (JONGERDEN; SIMSEK, 2018).

In view of this, the following analysis is intended to show how the media discourse on women fighters is constructed, and to identify in what ways this representation tends to reflect gender misconceptions and geopolitics interests. Although the repercussion of YPJ's achievements may have superficially suggested a recognition of their efforts, this paper argues that this recognition 
works at the expense of women's voices and of the feminist approach embraced by them. Moreover, it is embedded in many controversial aspects that serve to reinforce a very specific political narrative and to delegitimize others.

\section{Data analysis}

In view of the aforementioned, this section aims to analyze the terms referring to women fighters of the YPJ and how the media portrays them. Hence, in view of the hypothesis previously presented, data were extracted from the two most popular British online newspapers, BBC and The Guardian, between January 2014 and December 2018, to show that the representation of these women carries a strong sense of Westernized perception of their choices. Therefore, in this essay, the "Western depiction" is referred specifically to the nation mentioned above. That being stated, we have randomly selected fourteen news reports of female members of the YPJ from each of the chosen sources and analyzed them through MAXQDA software, which allowed the creation of visual representation of text data, giving greater prominence to words that appear more frequently in the overall documents.

Firstly, the keyword-in-context feature was employed, in which terms relevant to the analysis were searched in a tabular overview along with the fifteen words that appear before and after them and thus are part of their respective contexts. The selected terms were: "female", "women", and "YPJ". From these results, word clouds were elaborated to show the most common words associated to them. So that the graphic would not consist mainly of insignificant words, such as prepositions and connectives, a stop list was created to only include in the analysis terms essentially related to the research question. To that extent, we will verify the corroboration to our hypothesis through dividing the terms into categories of analysis such as: verbs, adjectives, warfare related terms and West related terms. Finally, we will apply the concepts of Orientalism linked to feminist arguments against gender misconceptions as our main scope of analysis to understand the context in which these terms were being used. 
Table 1 - Frequency of terms

\begin{tabular}{|c|c|c|c|c|c|c|c|}
\hline \multicolumn{8}{|c|}{ Frequency of terms extracted from news reports of BBC and The Guardian from 2014 to 2018} \\
\hline \multicolumn{2}{|c|}{ Verbs } & \multicolumn{2}{|c|}{ Adjectives } & \multicolumn{2}{|c|}{ Warfare related terms } & \multicolumn{2}{|c|}{ West related terms } \\
\hline Fight & $71 \%$ & Fighters & $89 \%$ & Forces & $60 \%$ & Purpose & $53 \%$ \\
\hline Kill & $57 \%$ & Protection & $46 \%$ & Battle & $50 \%$ & British & $32 \%$ \\
\hline Join & $28 \%$ & Support & $46 \%$ & War & $42 \%$ & Rights & $32 \%$ \\
\hline Defend & $25 \%$ & Soldiers & $32 \%$ & Military & $42 \%$ & Western & $21 \%$ \\
\hline Train & $17 \%$ & Militants & $32 \%$ & Front & $39 \%$ & & \\
\hline \multirow[t]{8}{*}{ Affiliate } & $14 \%$ & Rebels & $32 \%$ & Units & $39 \%$ & & \\
\hline & & Members & $17 \%$ & Frontline & $32 \%$ & & \\
\hline & & Activist & $14 \%$ & Armed & $25 \%$ & & \\
\hline & & Warriors & $10 \%$ & Ground & $21 \%$ & & \\
\hline & & Proud & $10 \%$ & Camp & $21 \%$ & & \\
\hline & & Slaves & $14 \%$ & Battalion & $17 \%$ & & \\
\hline & & Naive & $3 \%$ & Peace & $14 \%$ & & \\
\hline & & & & Guerrillas & $7 \%$ & & \\
\hline
\end{tabular}

Source: By the authors using MAXQDA software.

A primary analysis of the selected news reports about women in the YPJ shows that words in reference to bravery and heroism are often employed (Table 1). For instance, it was noticed that amongst verbs and adjectives the words "fighting" and "fighters" had the highest percentage of repetitions, 71 percent and 89 percent respectively. It is important to mention that the contexts in which these terms were used were often related to the YPJ's struggle against the Islamic State. As authors Amelie Malmgren and Michelle Palharini (2018, p. 55) point out, the way British media reports any news on the YPJ generally contextualizes them within counterterrorist campaigns of Western powers and, consequently, "neglects the ideology behind [YPJ] battle against fascism and patriarchal dominance and the self-defense of their own territory and people". Thus, the author argues how such perception also reinforces Said's categorization of "us vs. them" since it constructs a narrative through the idea that YPJ fighters are more aligned with Western values due to their choice to fight the IS.

In view of this, the cases of Anna Campbell and Shamima Begum come to light as a clear example of how British media tends to privilege women of the YPJ over, for example, female volunteers of the 
IS. Both Campbell and Begum were British-born citizens and illegally travelled to Syria to join the YPJ and IS respectively, nonetheless, the repercussions of each case were considerably different. Hence, Campbell was remembered in British media as "humanitarian" (JENKINS, [2018]), "fighter" (JENKINS, [2018]), "brave" (RAMASWAMY, [2019]), "British fighter" (VARDY, 2018), and many other adjectives that emphasized her commitment with the YPJ as a noble cause to be fighting for. On the other hand, Begum was not recognized as the IS fighter, but as simply jihadi bride or, to put better, "heartless little jihadi bride" (PEARSON, 2019). This is a powerful comparison we can use to draw a parallel of how the media uses the us vs. them dichotomy "since the framing of YPJ's fight against the background of counterterrorism presents an Orientalist discourse in which the UK (and more broadly the West) exerts the power of telling the truth" (MALMGREN; PALHARINI, 2018, p. 56).

Moreover, the prominence of such verbs reflects a process of conditional recognition of the struggle of Kurdish female fighters, in which, by focusing almost exclusively on their warfare efforts, the media omitted the political context of Rojava, the root-causes of the development of YPJ's fight and their entire philosophy. In a similar manner, as Table 1 shows, there is also a strong tendency to associate the work of these women with warfare terms. According to Dilar Dirik (2017, p. 18), such connotation owes to the West's fascination of associating the choices of these women with a world that is predominantly male and, the same time, links to Western attempts "to sensationalise the ways in which these women defy preconceived notions of eastern women as oppressed victims". Therefore, the reports sought to divorce their strive from its very specific political narrative and to frame the female fighters as an instrumental power in the use of states against IS (DEAN, 2019; ESKANDARI, 2018; JONGERDEN; SIMSEK, 2018). Thus, the problems with such perception arises from the fact that:

[...] instead of considering the implications of women taking up arms in what is essentially a patriarchal society - especially against a group that rapes and sells women as sexslaves - even fashion magazines appropriate the struggle of Kurdish women for their own 
sensationalist purposes. Reporters often pick the most "attractive" fighters for interviews and exoticise them as "badass" Amazons (DIRIK, 2017 p. 19).

These narratives directly link to the arguments made by Said and previously discussed that non-Western women are seen through a dichotomy of oppressed, due to the use of elements such as the veil, and, at the same time, as erotic and mysterious symbols which takes back to the figurations constructed around the imaginary of histories of harems and belly dancers (WEBER, 2001).

Furthermore, as Figure 1 and Figure 2 show, the most common adjectives used in the selected news have a positive meaning that seems to acknowledge the Kurdish female fighters' agency. By calling them "warriors", "soldiers" and "militants", the media creates a different notion of emancipated women who are not victimized by men but have their own purposes and ambitions. However, according to Brigitte Nacos (2005), when attempting to understand women who are acting in traditionally masculine roles, the media usually resorts to gender stereotypes and cultural or oriental clichés. Therefore, and as previously mentioned, the news tend to oversimplify female fighters real motivations, aspirations and rationale by connecting it with Western liberalism. Consequently, although these adjectives may express their agency as independent combatants, they also reinforce a particular geopolitical interest and overlook their real ideological reasons, as of equality and self-determination.

\section{Figure 1: "Female" word cloud}

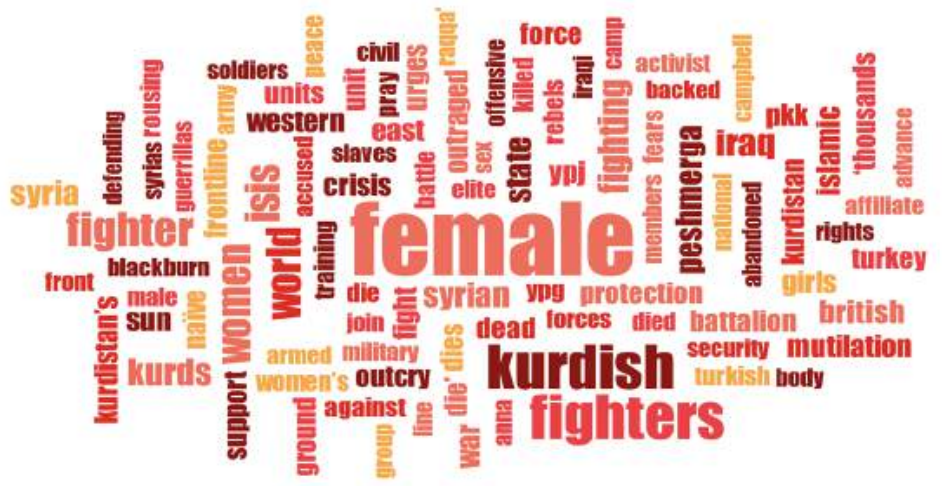

Source: By the authors using MAXQDA software. 


\section{Figure 2: "Women" and "woman" word cloud}

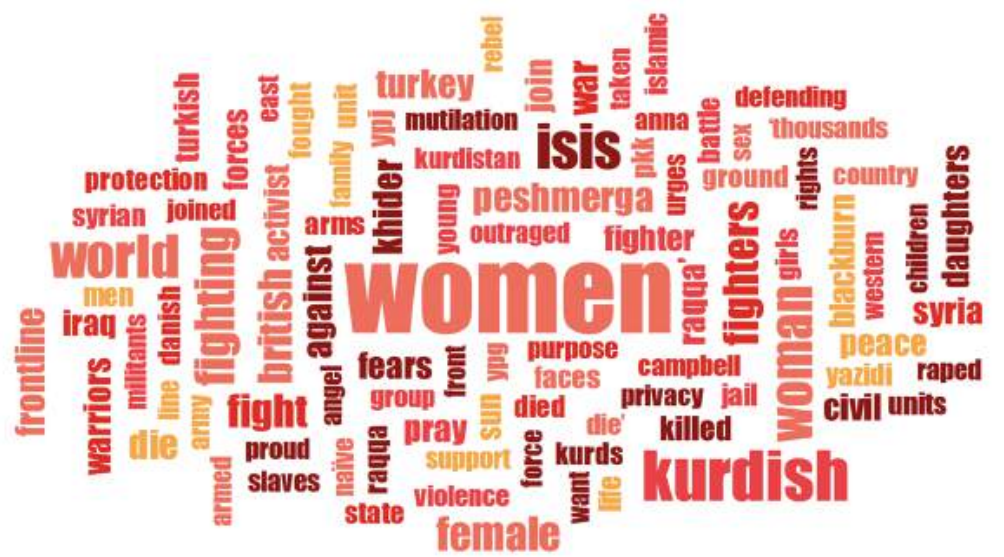

Source: By the authors using MAXQDA software.

In this regard, they are disconnected from the Kurdish movement's wider environment, and are portrayed as the heroes against the evil and as the representatives of a civilized West. Ergo, they are perceived as defenders of liberal and humanistic values, and their battle against the IS is mainly associated with Western ideological motivations (JONGERDEN; SIMSEK, 2018). In addition, as Figure 3 shows, the very use of the term "volunteers", commonly associated to the key word "YPJ", is also an expression of a Western classification of women's role in YPJ that falsely relates their choices with their exertion of agency in contrast, for instance, to how the IS female members are only referred to as brides, brainwashed and mostly influenced by their male counterparts. As author Katherine Brown (2012, p. 56) points out, such narratives only use female empowerment through "an instrumental sense rather than a good, or human right, in its own" whilst women's rights become a "side show in official [and mediatic] discourses".

In addition, according to Valentina Dean (2019), the Western fascination with YPJ fighters stems from the perception that they are an atypical and previously unexplored subject, and thus their representation is filled with inner contradictions and misconceptions. As women's involvement in political violence is still largely 
viewed as exceptional, their efforts in the YPJ were framed with amazement and admiration, in terms of a unique heroism depicted by the word "proud", for example. However, as Baser and Toivanen (2016, p. 14) asserts, "women who take part in armed battles to defend the "homeland" against an external threat, hold great symbolic value that can be strategically employed to legitimize the on-going battle". Therefore, in the context of the IS threat, such gendering in media framing may strongly contribute to the West's geopolitical objectives.

\section{Figure 3: "YPJ" word cloud}

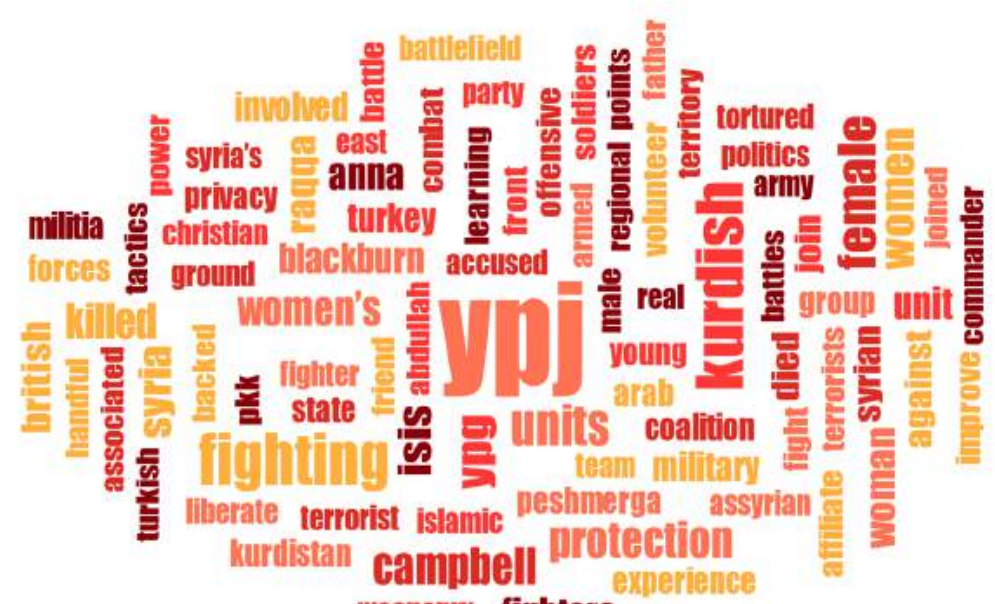

Source: By the authors using MAXQDA software.

Conclusively, the overall depiction of the YPJ's resistance against the IS is done in terms of a practical and military fight, not taking into account that women in Rojava are leading a political, social and ideological revolution which has extensive implications for the broader Kurdish movement. Female fighters are not just soldiers who fight to defeat a common enemy to the Western world, but they are "the contemporary protagonists in the construction of a different and democratic Middle East" claiming their identity into an inclusive system (DEAN, 2019, p. 25). 


\section{Conclusions}

As the analysis proposed in this paper suggested, the narratives around the involvement of women in political violence still carries a strong sense of deeply problematic gender misconceptions. The results drawn from the analysis of the news reports from $\mathrm{BBC}$ and The Guardian show that the way female fighters of the YPJ are represented in British media is based on stereotypes and gendered narratives. For instance, one notices that the media tended to privilege the YPJ's fight against the Islamic State over the former's ideology as well as struggle for independence. As a consequence, these women are framed within the campaigns to contain the IS which give the media the basis to sell their stories under the idea that they share so-called Western values and, therefore, are worth mentioned as fighters and warriors. At the same time, women's agency is not acknowledged and, even behind allegations of being referred to with positive adjectives, YPJ members are not exempt from gender misconceptions towards them.

Having said that, the contributions of Edward Said's Orientalism to the discussion addressed here were very important to give the background to understand the foundation in which the image of the women in the YPJ is constructed in the west. In this way, the findings in this paper also draw attention for the need to develop new ways of studying the involvement of women in violence. Hence, in addition to finding arguments to counter gender misconceptions within the literature, Orientalist contributions open space for investigating the misconceptions not only around the gender of the perpetrator of violence, but also how their actions are perceived and, consequently, represented and the interests behind such discourses.

\section{REFERENCES}

BARDIN, L. Análise de Conteúdo. São Paulo: Edições 70, 2011.

BARRETT, M. J. Making (Some) Sense of Feminist Poststructuralism in Environmental Education Research and Practice. Canadian Journal of Environmental Education, North Bay, v. 10, p. 79 - 93, 2005. Available at: https://files.eric.ed.gov/fulltext/EJ881776.pdf Accessed on: 20 Feb. 2020. 
BASER, B.; TOIVANEN, M. Gender in the representations of an armed conflict: Kurdish female combatants in French and British medias. Middle East Journal of Culture and Communication, Augusta, v. 9, n. 3, p. 294 - 314, 2016. Available at: https://pdfs.semanticscholar.org/9182/ e41cec303b0901c0f25952765777255c67b6.pdf Accessed on: 19 Feb. 2020.

BAHRAMITASH, R. The war on terror, feminist Orientalism and Orientalist feminism: Case studies of two North American bestsellers. Critique: Critical Middle Eastern Studies, Augusta, v. 14, n. 2, p. 221 - 235, 2005.

BROWN, K. E. Gender and counter-radicalization: women and emerging counter-terror measures: Katherine E. Brown. In: HUCKERBY, J.; SATTERTHWAITE, M. L. (eds.). Gender, National Security, and CounterTerrorism. London: Routledge, 2013. p. 49 - 72.

BUZAN, B. et al. The evolution of international security studies. Cambridge: Cambridge University Press, 2009.

DEAN, V. Kurdish Female Fighters: the Western depiction of YPJ combatants in Rojava. Glocalism: Journal of Culture, Politics and Innovation, New Dehli, n. 1, p. $01-29,2019$. Available at: https://glocalismjournal.org/wp-content/ uploads/2019/05/Dean_gjcpi_2019_1.pdf Accessed on: 19 Feb. 2020.

DIRIK, D. Syria: The revolutionary feminists fighting Isis. Green Left Weekly, Sydney, n. 1145, p. 17, 2017.

ESKANDARI, B. Victims, exotic warriors or heroines?: Framing the motivations of Kurdish female fighters in the war against Islamic State. Masters Dissertation (Social Sciences, Media and Communication Studies) - Lund University, Lund, 2018. Available at: http://lup.lub.lu.se/luur/down load?func $=$ downloadFile $\&$ recordOId $=8939596 \&$ fileOId $=8949982$ Accessed on: 19 Feb. 2020.

FERREIRA, B.; SANTIAGO, V. The Core of Resistance: Recognising Intersectional Struggle in the Kurdish Women's Movement. Contexto Internacional, Rio de Janeiro, v. 40, n. 3, p. 479 - 500, 2018. Available at: http://www.scielo.br/pdf/cint/v40n3/0102-8529-cint-2018400300479. pdf Accessed on: 19 Feb. 2020.

GALTUNG, J. Violence, peace, and peace research. Journal of Peace Research, Oslo, v. 6, n. 3, p. 167 - 191, 1969.

GAVEY, N. Feminist Poststructuralism and Discourse Analysis: contributions to feminist psychology. Psychology of Women Quarterly, Knoxville, v. 13, p. $459-475,1989$.

GORMAN, S. Are female counterinsurgency units effective? A case study of the female Kurdish militias of Iraq and Syria. Masters Dissertation (Arts in Liberal Studies) -School of Continuing Studies, The Graduate 
School of Arts and Sciences, Georgetown University, Washington, DC, 2017. Available at: https://repository.library.georgetown.edu/ bitstream/handle/10822/1043902/Gorman_georgetown_0076M_13622. pdf?sequence=1 Accessed on: 20 Feb. 2020.

HANSEN, A. Content Analysis. In: COTTLE, S. et al. (eds.). Mass Communication Research Methods. Houndmills: Palgrave Macmillan, 1998. p. $91-129$.

JENKINS, S. Anna Campbell's death in Syria was futile, but her passion was admirable. The Guardian, [online], [2018]. Available at: https://www. theguardian.com/commentisfree/2018/mar/19/anna-campbell-deathsyria-futile-britain-kurds\&gt. Accessed on: 30 Dec. 2019.

JONGERDEN, J.; SIMSEK, B. Gender Revolution in Rojava: The Voices beyond Tabloid Geopolitics. Geopolitics, Leiden, 2018. Available at: https://www.tandfonline.com/doi/pdf/10.1080/14650045.2018.1531283 ?needAccess=true Accessed on: 19 Feb. 2020.

MALMGREN, A.; PALHARINI, M. F. "Martyrs and Heroines" vs. "Victims and Suicide Attackers": A Critical Discourse Analysis of YPJ's and the UK media representations of the YPJ's ideological agency. Masters Dissertation (Media and Communication Studies) - Malmö University, Malmö, Sweden, 2018.

MANFRINATO, H. Islã, mídia e direitos humanos: políticas de representação e visibilidade a partir do agenciamento de uma rede de instituições islâmicas no pós-onze de setembro. Masters Dissertation (Masters in Social Anthropology) - Programa de Pós-Graduação em Antropologia Social, Universidade de São Paulo, Sâo Paulo, 2016.

MARTINI, A. Making women terrorists into "Jihadi brides": an analysis of media narratives on women joining ISIS. Critical Studies on Terrorism, Dunedin, v. 11, n. 3, p. 458 - 477, 2018.

NACOS, B. The Portrayal of Female Terrorists in the Media: Similar Framing Patterns in the News Coverage of Women in Politics and in Terrorism. Studies in Conflict \& Terrorism, Washington D.C., v. 28, n. 5, p. 435 - 445, 2005. Available at: https://doi.org/10.1080/10576100500180352 Accessed on: 28 Feb. 2020.

NARAIN, S. Gender in international relations: Feminist perspectives of J. Ann Tickner. Indian Journal of Gender Studies, New Dehli, v. 21, n. 2, p. 179 - 197, 2014.

PEARSON, E. Sorry my heartless little jihadi bride, but you made your bed and now you can lie in it. BBC News, [online], 14 Feb. 2019. Available at: https://www.telegraph.co.uk/news/2019/02/14/sorry-heartless-littlejihadi-bride-made-bed-now-can-lie/ Accessed on: 20. Oct. 2019. 
RAMASWAMY, C. Anna: The Woman Who Went to Fight Isis review - a daughter's bravery, a family's guilt. The Guardian, [online], [2019]. Available at: https://www.theguardian.com/tv-and-radio/2019/jul/03/ anna-the-woman-who-went-to-fight-isis-review-a-daughters-bravery-afamilys-guilt\&gt. Accessed on: 30 Dec. 2019.

RUIZ, T. Feminist Theory and International Relations: The Feminist Challenge to Realism and Liberalism. California State University Stanislaus Journal, Turlock, [s.v.], 2004. Available at: https://www. csustan.edu/sites/default/files/honors/documents/journals/soundings/ Ruiz.pdf Accessed on: 19 Feb. 2020.

SAID, E. Orientalism. London: [s.n.], 1978.

SJOBERG, L. Introduction to Security Studies: Feminist Contributions. Security Studies, Minneapolis, v. 18, n. 2, p. 183 - 213, 2009. Available at: http://dx.doi.org/10.1080/09636410902900129 Accessed on: 19 Feb. 2020 .

SHEPHERD, L. J. Sex or gender? Bodies in global politics and why gender matters. In: Gender matters in global politics: A feminist introduction to international relations. Londres: Routledge, 2015. p. 24 - 35.

SYLVESTER, C. Tensions in feminist security studies. Security Dialogue, Ottawa, v. 41, n. 6, p. 607 - 614, 2010.

THORBURN, D. Feminism Meets International Relations. SAIS Review, Baltimore, v. 20, n. 2, p. 01 - 10, 2000. Available at: https://doi.org/10.1353/ sais.2000.0051 Accessed on: 19 Feb. 2020.

TICKNER, J. A. Gendering World Politics. New York: Columbia University Press, 2000.

TRUE, J. Feminism. In: BURCHILL, S. et al. (eds.). Theories of International Relations. New York: St. Martin's Press, 1996. p. 244 - 264.

VARDY, E. British fighter: 'I can't go back to my own country'. BBC News, [online], 17 Oct. 2017. Available at: https://www.bbc.com/news/uk41648842 Accessed on: 28 Feb. 2020.

WEBER, C. Unveiling Scheherazade: Feminist Orientalism in the International Alliance of Women, 1911-1950. Feminist Studies, College Park, v. 27, n. 1, p. 125 - 157, 2001.

WEEDON, C. Feminist Practice \& Poststructuralism Theory. Oxford: Blackwell, 1989.

WILCOX, L. Gendering the Cult of the Offensive. Security Studies, Ottawa, v. 18, n. 2, p. 214 - 240, 2009. Available at: http://dx.doi. org/10.1080/09636410902900152 Accessed on: 19 Feb. 2020. 